\title{
Diagnosis and prevalence of Congenital Adrenal Hyperplasia (CAH) in Austrian children screened or not screened for $\mathrm{CAH}$
}

\author{
Katharina Luxenberger ${ }^{1}$, David Kasper ${ }^{2}$, Elke Fröhlich-Reiterer ${ }^{1}$, Elisabeth Suppan ${ }^{1}$, Gudrun Weinhandl ${ }^{1}$, \\ Martin Borkenstein ${ }^{1 *}$
}

From 7th APPES Biennial Scientific Meeting

Nusa Dua, Bali. 14-17 November 2012

Prevalence of Congenital Adrenal Hyperplasia (CAH) is not exactly known in the Austria; a number of patients with CAH might not be diagnosed, especially males. CAH is in about $95 \%$ of the cases due to a defect in the 21 hydroxylation ('classical CAH'). Newborn screening for $\mathrm{CAH}$, based on the measurement of $17 \alpha$-hydroxyprogesterone (17-OHP) was shown to be efficient for diagnosis, and is part of the newborn screening programme in Austria since April 2001.

In our study we compared 2 groups of children:

Group A, children born in Styria (a province of Austria), $1992-2001, \mathrm{n}=119.001, \mathrm{~m}$ 61.256, and f 57.745;

Group B, children born in Styria $2002-2011, \mathrm{n}=$

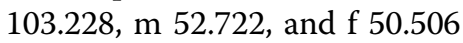

In group A (patients not screened), $\mathrm{CAH}$ was diagnosed in 8 children (m 4; $\mathrm{f} \mathrm{4);4}$ of them with simple virilising (SV) 21-OH deficiency (m 3; f 1 ) and 4 with salt wasting (SV) 21-OH deficiency (m 1; f 3).

In group B, 98,7 \% of all newborns born in Styria could be screened by measuring 17-OHP in a dried blood spot on filter paper. Recall rate was $0,578 \%$. CAH was diagnosed in 10 children (m 3: f 7). 8 of them with $\mathrm{SW}(\mathrm{m} \mathrm{2} ; \mathrm{f} 6)$, and 2 with $11 \beta$-hydroxylase deficiency (m 1; f 1).

Whereas group A displayed the expected Mendelian sex ratio, group B showed a strong female predominance (m 3; f 7)

Prevalence of $\mathrm{CAH}$ was 1:14.875 newborns in group A (not screened). In group B (newborns screened) prevalence was 1:10.132.

'Departments of Pediatrics and Adolescence Medicine, Medical Universities Graz, Graz, Austria

Full list of author information is available at the end of the article
If one exclude the 2 patients with $11 \beta$-hydroxylase deficiency from group B, prevalence of 'classical CAH' was 1:14.875 in group A, compared to 1:12.903 in group B.

These data show that newborn screening for $\mathrm{CAH}$ seems to increase the rate of detection of $\mathrm{CAH}$.

\section{Authors' details}

'Departments of Pediatrics and Adolescence Medicine, Medical Universities Graz, Graz, Austria. 'Departments of Pediatrics and Adolescence Medicine,

Medical Universities Vienna, Vienna, Austria.

Published: 3 October 2013

doi:10.1186/1687-9856-2013-S1-P111

Cite this article as: Luxenberger et al:: Diagnosis and prevalence of Congenital Adrenal Hyperplasia (CAH) in Austrian children screened or not screened for CAH. International Journal of Pediatric Endocrinology 2013 2013(Suppl 1):P111.

Submit your next manuscript to BioMed Central and take full advantage of:

- Convenient online submission

- Thorough peer review

- No space constraints or color figure charges

- Immediate publication on acceptance

- Inclusion in PubMed, CAS, Scopus and Google Scholar

- Research which is freely available for redistribution 